\title{
Freud y los no europeos: el mito de la identidad colectiva
}

«Dudo mucho que Freud imaginara que tendría lectores no europeos o que, en el contexto de la lucha por Palestina, tendría también lectores palestinos; pero los tuvo y los tiene». Palabra del eminente profesor Edward W. Said (Jerusalén, 1935), catedrático de Filología Inglesa y Literatura Comparada de la Universidad de Columbia. Nueva York. Expulsado de su Palestina natal -su familia pertenecía a la minoría cristiana de Líbano- se formó en USA, y fue hasta su muerte (2003) un pacífico defensor de la Causa Palestina. Polifacético y erudito, Said fue un potente analista de nuestra cultura Occidental que utilizó la literatura como instrumento de trabajo, como microscopio, cuando no como bisturí. También fue musicólogo y con Daniel Barenboim creó un taller para reunir a jóvenes músicos israelíes y árabes. Ambos recibieron en el 2002 el Premio Príncipe de Asturias de la Concordia.

De sus ensayos publicados, destacan: Orientalismo, un exhaustivo análisis de las representaciones literarias occidentales de Oriente; Cultura e imperialismo, con traducción de lujo de Nora Catelli; Beginnings, donde se puede encontrar un análisis literario de La Interpretación de los sueños de Freud; La cuestión de Palestina, que trata sobre los mecanismos psicológicos que se dan en la negación de la existencia del otro; Crónicas del exilio, y sus memorias Fuera de lugar.

Dado su prestigio internacional y conocidos sus estudios sobre la obra de Freud, el Instituto y Museo Freud de Viena invitó al profesor Said (dos años antes de morir de leucemia, que lo atenazaba desde hacía trece años), a realizar la conferencia anual sobre Freud. Said aceptó y propuso el título: Freud y los no europeos. La conferencia, dice el autor, quería reivindicar, entre otras cosas, el pensamiento cosmopolita de Freud en oposición al provincialismo de sus contemporáneos «que denigraban otras culturas no europeas como menores o inferiores». Tres meses antes de la fecha señalada, el Instituto vienés comunicó a Said que se había decido anular su conferencia a causa de la situación política en Oriente Próximo. Said pidió explicaciones, pero no se las dieron. Poco después se supo que la exposición con documentos de Freud -que se había exhibido en Viena y Nueva York- se quería llevar a Israel. «Según parece, los potenciales patrocinadores exigieron la cancelación de mi conferencia como condición para financiar la exposición en Tel Aviv. Los sumisos miembros del Consejo de Viena cedieron y mi conferencia se anuló, no porque yo abogara por la violencia y el odio, isino porque no lo hago!». Antes de que acabara ese mismo año, el Museo Freud de Londres le abrió las puertas a Said para que pronunciara su conferencia. La histo- 
ria se repite sesenta y tres años después. Freud por judío y Said por palestino son negados en Viena; y ambos, acogidos en Londres.

De reciente publicación en nuestro país (Barcelona, Global Rhithm, 2005), esta conferencia es una lectura política y actualizada de Moisés y la religión monoteísta. Para situar al lector en este ensayo tan complejo de Freud, jibarizó al máximo el texto con la ayuda de Jorge Belinsky. La cita corresponde a su ensayo Bombones envenenados: "Como se sabe, durante el reinado de Amenhotep IV (Ikhnatón) se desarrolló en Egipto un culto monoteísta alrededor de la figura del dios solar Atón. El proyecto de Ikhnatón fracasó y tras su muerte los sacerdotes egipcios de Amón restauraron las formas politeístas anteriores. Sin embargo, según el relato freudiano un miembro de la casa real egipcia, Moisés, decidió llevar adelante el fracasado proyecto de Ikhnatón. Para ello escogió al pueblo cautivo de Israel, al cual impuso ese proyecto, con rasgos más duros incluso, ya que la figura misma del dios solar desaparece en beneficio de la de un Dios cuya representación queda prohibida. Los israelitas, díscolos y rebeldes, terminan por asesinar al extranjero noble, cuyo liderazgo habían aceptado al principio, y reprimen luego el recuerdo de ese acto. Transcurrido el tiempo, bajo el peso de la culpa y la añoranza, parte de lo reprimido retorna: el pueblo de Israel adopta el severo monoteísmo de Moisés, pero éste, en el interregno, se ha transformado definitivamente en judío. La intención política del texto de Freud es clara: si cada pueblo para formarse una imagen de sí ha de interrogarse por sus orígenes, debe aceptar que no hay comienzo absoluto porque siempre existen antecedentes y precursores (que son los otros o el Otro anterior)».

Esa intención política del texto es juntamente la que Said hace suya para abogar por la Causa Palestina. Al retomar la historia primitiva de la identidad judía descrita por Freud, Said cuestiona de raíz el origen fundacional de la identidad judía y los derechos históricos que alega el sionismo sobre Palestina. Si hay una Tierra prometida y también perdida, Said nos recuerda que Freud la situó en Meribat-Cades, «al sur de Palestina, entre las estribaciones orientales de la península de Sinaí y el límite occidental de Arabia. Allí los judíos adoptaron el culto a un dios llamado Yahvé, que provenía probablemente de la tribu árabe de los madianitas, que habitaba las comarcas vecinas». Said nos dice que el texto de Freud «socava la originalidad judía al señalar que, en primer lugar, la circuncisión era una idea egipcia y no hebrea; y, en segundo, que seguramente los levitas, un grupo judaico que según la convención existió siempre, eran seguidores egipcios de Moisés, que se habrían trasladado con él al nuevo lugar».

La política del estado de Israel que practica desde su fundación en 1948, el quitate tú para ponerme yo, es la que Said critica empleándose a fondo. Para ello no duda en meter el dedo en la fisura de la identidad de Freud que él mismo nos muestra en su texto Moisés y la religión monoteísta. Publicado en su último año de vida 
SALUD MENTAL Y CULTURA

y a punto de empezar la Segunda Guerra Mundial, nos deja al descubierto su incomoda relación con la ortodoxia judía y sobre todo nos transmite su ambivalente relación respecto de su propia judeidad. «Afirmar que la relación de Freud con el judaísmo era conflictiva es quedarse corto». Al definirse Freud como un judío sin Dios, Said lo pone como ejemplo frente a los que utilizan a Yahvé como garantía de su identidad y, la consecuencia que de ello se deriva, la negación a la existencia del otro. Dice Said: «La legislación israelí, lejos del espíritu que anima las advertencias deliberadamente provocativas de Freud sobre el origen no judío del fundador del judaísmo y de los inicios de éste en el ámbito del monoteísmo egipcio no judío, contraviene, reprime e incluso anula la apertura de la identidad judía, que Freud tan meticulosamente sostiene, hacia sus antecedentes no judíos. El Israel oficial ha eliminado los complejos estratos del pasado. Actualmente, esta otra historia, ni judía ni europea, se ha borrado, y es ya imposible descubrirla en la identidad judía oficial». Realmente es sintomática la insistencia en construir un gran Israel -territorios ocupados incluidos- exclusivo para los judíos. Para Said, lo que insiste es síntoma de que retorna lo que de reprimido existe. «Creo que estoy en lo cierto al suponer-dice el profesor Said- que Freud movilizó el pasado no europeo con el fin de socavar cualquier intento doctrinal que pudiera hacerse para dotar a la identidad judía de una base fundacional sólida, ya fuera ésta religiosa o secular». Said afirma que Freud se niega a «reducir la identidad a la pertenencia a uno de esos rebaños nacionalistas o religiosos a los que tanta gente quiere unirse a toda costa; (...) incluso para la más definible, identificable y refractaria identidad común, hay límites inherentes que impiden que pueda incorporarse exclusivamente a una sola y única Identidad (...). En otras palabras, la identidad no puede concebirse ni funcionar como si fuera algo puro; no puede constituirse ni siquiera imaginarse sin la represión de esa radical fractura o carencia originarias...». Leyendo a Freud, Said reconoce que la identidad es un problema no resuelto, un conflicto que no prescribe, por eso cree que en esta experiencia psicológica reside la esencia de lo cosmopolita y que por lo tanto algún día será posible que «en la tierra de judíos y palestinos, pueda establecerse un estado binacional en el que Israel y Palestina sean dos partes y no dos antagonistas». Amén.

En el libro que nos ocupa también aparece la réplica a la conferencia de Said que corrió a cargo de Jacqueline Rose, catedrática de inglés de la Universidad de Londres, crítica feminista y estudiosa de la sexualidad femenina juntamente con Juliet Mitchel; judía, escritora, traductora y editora de Moustapha Safouan (psicoanalista francés de origen egipcio). Jacqueline Rose empieza elogiando la lectura que Said realiza de Freud ya que no se basa en lo que se entendió o dejó de entender en su época, sino en una lectura actualizada: «Una parábola política para nuestra época».

De todas maneras, le expone dos peros, aunque no desacuerdos. Uno: si bien es cierto que Freud nos habla de las conflictivas tensiones de su identidad como judío, con el fin de reflexionar sobre la fisura o herida en el corazón de la identi- 
dad colectiva, no es menos cierto que el mismo año en que niega su apoyo a la fundación de un estado judío en Palestina (1930) escribe en el prólogo a la edición hebrea de Tótem y tabú lo siguiente: «A ninguno de los lectores, le resultará fácil situarse en el clima emocional de un autor que desconoce el lenguaje de las Santas Escrituras, que está apartado de la religión de sus antepasados -así como de cualquier otra religión-, que no puede participar de los ideales nacionalistas, pero que, no obstante, nunca ha renegado de la pertenencia a su pueblo, que se siente judío y no desea que su naturaleza sea otra. Si alguien le preguntara, ¿pero qué queda de ti de judío si has renunciado a todos esos elementos comunes con tu pueblo?, le respondería: muchas cosas, quizá lo esencial». Para Jacqueline Rose ésta es la definición de un judío secular moderno, alguien «para quien despojarse de los atavíos de la identidad lingüística, religiosa y nacional -desmontados paradójicamente, los elementos insostenibles y, por así decirlo, políticamente más peligrosos- no le hace menos judío, sino más». Esto quiere decir que la identidad en Freud está en falta pero no puede faltar. «Creo que la estabilidad de la identidad -para Freud y para cualquiera de nosotros es algo de lo que resulta difícil escaparmás difícil de lo que Said, por motivos absolutamente admirables, desea». Claro que en Moisés y la religión monoteísta nos habla «de las identidades conocedoras de su propia provisionalidad, pero también hace lo contrario». La autora cree que este texto es uno de los más violentos de Freud y «puede leerse como la historia de un asesinato político en donde se sostiene la tesis, ya apuntada en Tótem y tabú, de que el asesinato es constitutivo del vínculo social (...). No existe sociabilidad sin violencia y lo que une a las personas con más fuerza y eficacia es aquello que han acordado odiar. El vínculo que une a las personas entre sí y ellas con su Dios es el asesinato». Lo que une pues a un pueblo también es la consecuencia de ese crimen, es decir, su trauma.

«Ésta es la otra mitad de la historia -le dice la autora a Said, a modo de segundo pero-, pues el trauma lejos de generar libertad, apertura tanto hacia los demás como hacia los fragmentos divididos y no resueltos del propio yo, conduce a una clase de fragmentación muy distinta -devastadora, en palabras del propio Freud-, que provoca el crecimiento de las identidades en una dirección totalmente contraria: hacia el dogmatismo y los peligros de formas de fe opresivas y represoras (léase actuales fundamentalismos). ¿Estaremos corriendo el riego de idealizar las grietas y fisuras de la identidad?» Para esta autora una cosa es que para existir como un ser social hay que estar bastante loco y otra cosa es una desestructuración psicótica productiva, es decir, delirante. ¿Qué es sino la limpieza de sangre versus baño de sangre? Por los ejemplos de las últimas carnicerías J. Rose no puede ser muy optimista: «Creo que también Freud era poco optimista, no sólo porque, como Edward Said dice, la historia reprime la falta, sino porque la repetición es históricamente la respuesta más frecuente al trauma». Y una última obser- 
SALUD MENTAL Y CULTURA

vación de la autora al conferenciante. «Esta noche, Edward Said ha rendido a Freud un homenaje extraordinario al extraer de la última obra de éste una visión de la identidad capaz de moverse por encima de los peligros que la identidad plantea en nuestra época. Si disiento levemente de él no es sólo porque no estoy segura de que Freud lo hiciera, sino también porque al mirar el mundo que nos rodea, me pregunto si alguno de nosotros conseguirá hacerlo algún día». Sin embargo esta autora cita a Marc Ellis, profesor de estudios americanos y judíos en la Universidad de Baylor, que plantea lo siguiente: «¿Qué ocurriría si el centro de Jerusalén contemporáneo se viera como un lugar fragmentado y no un lugar redentor, y pudiera compartirse en su fragmentación en lugar de ser dividido por la victoria y la derrota?». Dos películas recientes sobre el conflicto entre israelíes y palestinos plantean la misma cuestión, al tiempo que nos muestran la manipulación ideológica de la identidad nacional: Promises y Paradise now.

¿Quién puede, pues, presumir de un origen absoluto, de un acto fundacional puro? Nosotros, al pertenecer a la cultura llamada Occidental y definida como judeocristiana bien podemos aplicarnos tres cuartos de lo mismo dicho por Said, y además por partida doble, ya que si Moisés nació egipcio Jesucristo nació judío. Los cristianos y católicos ya nacemos con ese Pecado Original. Todos... menos una mujer llamada La Virgen María, sin pecado concebida. Piruetas teológicas al margen, la cuestión es que a todos los demás mortales se nos inocula al nacer la culpa para mejor sobrellevar el trauma colectivo: el crimen de nuestros padres. Mácula que se borra con el agua bendita del bautismo. Desde entonces, nuevos o viejos, muchos somos los conversos y todos exiliados en tanto que expulsados del paraíso terrenal. Y en este mundo globalizado en que nos ha tocado vivir somos más desplazados, refugiados, emigrantes, y más extranjeros entre y para nosotros mismos. Si el origen no fue puro el final pinta que será mestizo. Otra lectura nos cantaría -literaria que no literal- si tomáramos el acto fundacional como lo que es, es decir, una narración, un mito que, como todo buen relato, permite la identificación pero no exige la fusión-con lo novelado: la con-fusión. Si la verdad histórica es un agujero la novela histórica es la ficción necesaria para bordearlo y no precipitarnos en su profundidad y oscuridad.

No sé si es de recibo hablar de Psicología de las masas, pero es evidente que este libro y Masa y Poder -tal como nos lo dejó escrito Elias Canetti- están tan unidos como Ortega y Gasset. Me pregunto si como colectivo psi podemos aportar una idea sobre la identidad colectiva -más o menos unitaria y que nos la validen científicamente- que vaya más allá de la identidad colectiva como rédito político, es decir, como imaginario social construido por la ideología política y/o religiosa dominante. La subjetividad que se deriva como consecuencia de esa construcción política e imaginaria sí que es observable en la psicología individual del caso por caso. Existen identidades blindadas, divididas, fragmentadas, y en el 
mejor de los casos sólo escindidas. Un caso práctico: el escritor líbanofrancés Amin Maalouf (Líbano, 1949), autor del ensayo Identidades asesinas, nos refiere su propio caso. «Desde que dejé Líbano en 1976 (como consecuencia de la guerra) para instalarme en Francia, cuántas veces me habrán preguntado, con la mejor intención del mundo, si me siento más francés o más libanés. Y mi respuesta es siempre la misma: ¡Las dos cosas! Y no porque quiera ser equilibrado o equitativo, sino porque mentiría si dijera otra cosa. Lo que hace que sea yo, y no otro, es ese estar en las lindes de dos países, de dos o tres idiomas, de varias tradiciones culturales. Eso es justamente lo que define mi identidad. ¿Sería acaso más sincero si amputara de mí una parte de lo que soy? ¿Medio francés y medio libanés entonces? ¡De ningún modo! La identidad no está hecha de compartimentos, no se divide en mitades, ni en tercios o en zonas estancas. Y no es que tenga varias identidades: tengo solamente una, producto de todos los elementos que la han configurado mediante una dosificación singular que nunca es la misma en dos personas. Y cuando a nuestros contemporáneos se los incita a que afirmen su identidad, como se hace hoy tan a menudo, lo que se les está diciendo es que rescaten del fondo de sí mismos esa supuesta pertenencia fundamental, que suele ser la pertenencia a una religión, una nación, una raza o una etnia, y que la enarbolen con orgullo frente a los demás. Los que reivindican una identidad más compleja se ven marginados». Tanto Amin como Said son partidarios de cultivar una subjetividad rigurosa, ni complaciente ni resentida.

* Carlos Rey es psicólogo y psicoanalista.

Correspondencia: carlosry@copc.es

** Fecha de recepción: 8-X-2007 (aceptado el 21-XII-2007). 